\title{
Financing Risk in Indonesian Islamic Rural Banks: Do Financing Products Matter?*
}

\author{
Agus WIDARJONO ${ }^{1}$, M.B. Hendrie ANTO², Faaza FAKHRUNNAS ${ }^{3}$ \\ Received: July 03, 2020 Revised: July 19, 2020 Accepted: August 10, 2020
}

\begin{abstract}
This paper investigates the impact of profit and loss sharing (PLS) contracts on non-performing financing of Islamic rural banks as Islamic small banks focus on small and medium enterprises at province level across country. Our study employs panel data, consisting of 142 Islamic rural banks and using quarterly data from 2013Q1 to 2018Q4, and splits them based on the bank's size and geographical area. Both static and dynamic panel regressions are then applied. The results obviously indicate that a high proportion of profit and loss sharing contracts leads to high financing risk. The large Islamic banks encounter a higher non-performing financing stemming from profit and loss contracts compared to small Islamic banks. Profit and loss contracts also produce higher financing risk for Islamic banks outside Java, as those areas are less developed areas than Java itself. A more efficient Islamic bank is less financing risk. Income diversification lessens the impaired financing and, more particularly, large Islamic banks and Islamic banks located in Java much benefit by diversifying income and financing to lower financing risk. Our study suggests that Islamic rural banks may consider the optimal level of profit and loss sharing contracts to minimize financing risk.
\end{abstract}

Keywords: Non-Performing Financing, Profit and Loss Sharing Financing, Islamic Rural Bank, Indonesia

JEL Classification Code: G21, G24, G28

\section{Introduction}

In principle, Islamic banks must comply with Islamic rules that prohibit interest rates and any speculative transactions such as gambling and excessive uncertainty

\footnotetext{
*Acknowledgements:

This research was fully funded by the Indonesian Ministry of Research, Technology, and Higher Education, (Grant number: 025/ ST-DirDPPM/70/DPPM/PEN.DASARUPT-KEMENRISTEKDIKTI/ III/2019).

${ }^{1}$ First Author and Corresponding Author. Associate Professor, Department of Economics, Faculty of Business and Economics, Universitas Islam Indonesia, Yogyakarta, Indonesia [Postal Address: Kampus Condong Catur, Depok, Sleman, Yogyakarta, 55283, Indonesia] Email: agus.widarjono@uii.ac.id

${ }^{2}$ Lecturer, Department of Economics, Faculty of Business and Economics, Universitas Islam Indonesia, Yogyakarta, Indonesia. Email: hendrie@uii.ac.id

${ }^{3}$ Lecturer, Department of Economics, Faculty of Business and Economics, Universitas Islam Indonesia, Yogyakarta, Indonesia. Email: fakhrunnasfaaza@uii.ac.id Non-Commercial License (https://creativecommons.org/licenses/by-nc/4.0/) which permits unrestricted non-commercial use, distribution, and reproduction in any medium, provided the unrestricted non-commercial
original work is properly cited.
}

(Hassan \& Aliyu, 2018). Instead of the loan based on the interest-based system, the Islamic bank offers financing products, not only profit and loss sharing (PLS), but also nonprofit and loss-sharing (non-PLS) contracts. An Islamic bank providing PLS contracts such as mudharaba and musyaraka encounters a high risk financing because PLS contract leads to moral hazard, asymmetric information, and adverse selection (Azmat, Skully, \& Brown, 2015). Therefore, the PLS contract leads to a greater probability of impaired financing. Kabir, Worthington, and Gupta, (2015) found that the Islamic bank has higher non-performing financing (NPF) than a conventional bank.

There is something unique about the practice of Islamic banking in Indonesia. Islamic banks in Indonesia consist of Islamic commercial banks that operate at the national level as a large Islamic bank, and Islamic rural banks, which operate at the province level as a small Islamic bank. Islamic rural banks concentrate on financing for micro, small and medium firms, which constitute the largest proportion of enterprises in Indonesia. Therefore, Islamic rural banks (IRB) are one of the important financial intermediaries in the Indonesian economy. At present, there are 36,000 small and medium industries, while large industries total approximately 1,000. 
The number of IRBs throughout Indonesia is 160 with total assets of IDR (Indonesian Rupiah) 12.36 trillion in 2018. Furthermore, IRBs must also be able to compete with conventional rural banks (CBRs) as their competitors. The number of conventional rural banks was 1,764 banks with total assets of IDR135.693 trillion in 2018.

Similar to an Islamic commercial bank, IRB also provides both PLS and non-PLS contracts for its financial contract. The PLS contracts consist of mudharaba and musyaraka. Mudharaba is a contract between an Islamic bank and its borrower to which profits and losses are shared between them. Musyarakah is a joint venture contract where an Islamic bank and its customer provide capital and both manage jointly the project. Profit and losses are shared according to the contribution of each party. By contrast, nonPLS is based on sales principles encompassing murabaha as a cost-plus scheme, Ijarah as a leasing contract, salam as a forward contract, Istishna as a manufacturing contract, Qardh as a benevolence contract and multi-purpose financing contract. The Indonesian Financial Services Authority, as the IRB regulator, establishes a maximum limit of NPF by $5 \%$. Financing risk of Islamic banks, generally, is higher than that of conventional bank as their counterparts (Sutrisno \& Widarjono, 2018). Indeed, NPF of IRB is also higher than non-performing loan (NPL) of CRB, which measures a loan risk for the conventional bank. The average NPF of IRB per month during $2011-2018$ was $8.76 \%$, while the average NPL of CRB was $5.94 \%$. However, both NPF and NPL have been increasing since 2014. With high NPF, IRBs are very vulnerable to bankruptcy as compared to CRBs.

Our study examines the impact of PLS contracts, Islamic bank characteristics, and macroeconomic variables on the financing risk of Islamic rural banks in Indonesia. This paper contributes to the body of knowledge in several ways. First, many studies have investigated the financing risk of large Islamic commercial banks (e.g., Kabir \& Worthington, 2017; Hassan, Khan, \& Paltrinieri, 2019) as well as large conventional banks (e.g., Tran \& Nguyen, 2020; Le \& Diep, 2020). The previous empirical studies, to the best of our knowledge, have not dealt with issues about the financing risk of small Islamic banks. Indeed, some previous studies have investigated the financing risk of conventional banks in Indonesia (Rachman, Kadarusman, Anggriono, \& Setiadi, 2018). Second, our study especially investigates PLS contracts in determining non-performing financing to which PLS contracts likely cause high impaired financing (Warninda, Ekaputra, \& Rokhim, 2019).

\section{Literature Review}

A number of previous empirical studies have applied NPF or NPL as a proxy for financing (credit) risk in both conventional banks and Islamic banks. NPF, which is a ratio of the total amount of impaired financing to the total amount of financing, represents the asset quality of the Islamic bank. There are two advantages of the NPF for measuring Islamic bank insolvency. First, NPF is simple and directly measures bank insolvency. Second, NPF is difficult to be manipulated by management. NPF is the most important factor leading to Islamic banks being reluctant to providing financing. A high rate of NPF leads banks to hike more provision up for financing loss so that it lowers the Islamic bank's revenue by trimming down the funds for new financing. Moreover, a high NPF indicates the increased probability of bank insolvency.

Research on the non-performing financing of Islamic banks has been widely conducted. Abedifar, Molyneux, and Tarazi (2013) used 553 Islamic banks from 24 countries between 1999 and 2009 to investigate the risk of Islamic banks, which is calculated by a ratio of loan-loss reserves to gross loans. The findings prove a negative relationship between size and financing risk, which is consistent with possible diversification and benefit from economies of scale. They also documented that higher domestic interest rates affect positively on financing risk. Trad, Trabelsi, and Goux (2017) examined Islamic financing risk for 78 Islamic banks in 12 countries, covering the period from 2004 to 2013. Bank size and capital negatively affect financing risk. The result indicates that the more fluid the Islamic banks, the lower its financing risk. Both macroeconomic variables, namely, GDP and inflation, have a positive influence on financing risk. Indeed, the GDP should have a negative impact on financing risk as good economic condition leads to a better economic environment, so it lowers impaired financing.

Beck, Demirgüç-Kunt, and Merrouche (2013) investigated the NPF to measure asset quality of both conventional and Islamic banks across 22 countries from 1995 to 2009, comprising 510 banks, out of which 88 are Islamic banks. Their results showed that Islamic banks have higher asset quality or lower NPF, and non-loan earning assets have a positive impact on NPF. Rahim and Zakaria (2013) examined the stability between Islamic and conventional banks in Malaysia, spanning from 2005 to 2010. Based on NPF, it shows that, on average, Islamic banks are apparently steadier than their conventional banks. The findings of the study indicate that variables that have been recognized as the important elements towards NPF for Islamic banks were loan asset ratio, cost-income ratio, total assets, Herfindahl Index, inflation and real GDP, while conventional bank stability was influenced by loan asset ratio, total assets, income diversity, Herfindahl Index, and real GDP. Mirza, Rahat, and Reddy (2015) assessed the potential distinctions in business, asset quality and financial stability, efficiency, Shariah-compliant banks and non-banking financial institutions in Pakistan employing an unbalanced panel in 2005 and 2013. They found that 
Islamic bank has lower NPF and GDP, and market share has a negative impact on NPF.

Kabir, Worthington, and Gupta (2015) investigated the financial risk in Islamic and conventional banks across 13 countries between 2000 and 2012, consisting of 37 Islamic banks and 156 conventional banks. They found that Islamic banks show higher NPF than those of conventional banks. Assets negatively affect NPF. This condition denotes that larger banks seem to have lower financing risk. Large banks generally can capture the benefit of economies of scale, which supports Islamic banks to manage their credit risk better. The ratio of cost to income has a positive impact on the NPF. ROA demonstrates a significant negative relationship with NPF so that banks which have better risk management skill refer to profitable banks. Diversification of income also reveals a negative impact on NPF. GDP negatively affects credit risk but inflation has a significant positive impact on NPF.

The empirical study on financing risk between Islamic banks and conventional banks yields unclear results. An Islamic bank has lower NPF than a conventional bank due to its inflexible financing contracts. First, Islamic bank has limited investment contracts because it complies with the Shariah principles, so it has less excessive financing than a conventional bank (Hussein, 2010; Waemustafa \& Sukri, 2016). Second, an Islamic bank is prohibited from any speculative contract, so it is less influenced by any economic shock, and the probability of bad financing is low (Abdulle \& Kassim, 2012; Beck, Demirgüç-Kunt, \& Merrouche, 2013; Rahim \& Zakaria, 2013; Hussien, Alam, \& Murad, 2019). By contrast, several empirical studies proved that Islamic bank has higher NPF than a conventional bank. Lassoued (2018) reported that Islamic bank has higher financing risk than a conventional bank because of its higher NPF. Financing contracts such as mudharaba and musyaraka as a profit-sharing system causes agency problems which lead to a greater NPF.

\section{Research Method and Materials}

\subsection{Model Specification}

This study follows the previous empirical studies in investigating non-performance financing of IRB in Indonesia, including Islamic bank characteristics and macroeconomic variables (e.g., Beck, Demirgüç-Kunt, \& Merrouche, 2013; Ghenimi, Chaibi, \& Omri, 2017; Mahdi \& Abbes, 2018; Hassan, Khan, \& Paltrinieri, 2019). The model of Islamic rural banking risk can be expressed in the following panel regression equation:

$$
\begin{aligned}
\mathrm{NPF}_{i t}= & \beta_{0}+\beta_{1} \mathrm{PLS}_{i t}+\beta_{2} \mathrm{LASSET}_{i t}+\beta_{3} \mathrm{CAR}_{i t} \\
& +\beta_{4} \mathrm{LLP}_{i t}+\beta_{5} \mathrm{OER}_{i t}+\beta_{6} \mathrm{INCDIV}_{i t} \\
& +\beta_{7} \mathrm{FINDIV}_{i t}+\beta_{7} \mathrm{GGRDP}_{i t}+\mathrm{e}_{i t}
\end{aligned}
$$

Where $i$ represents the level of Islamic bank and $t$ shows the time dimension.

Based on equation (1), IBR's financing risk is a function of both Islamic rural bank characteristics and macroeconomic variables. The Islamic bank characteristics consist of PLS financing, total asset (ASSET), capital asset ratio (CAR), loan loss provisions over total financing (LLP), operational efficiency ratio (OER), income diversification (INCDIV), and financing diversification (FINDIV). The macroeconomic variable is the growth of domestic regional product (GRGDP). The asset is expressed in a natural logarithm.

PLS is the PLS financings over total financing, which measure the proportion of PLS financings. PLS contracts apparently cause a moral hazard, asymmetric information, and adverse selection (Azmat, Skully, \& Brown, 2015). A high proportion of PLS contracts is high financing risk. Accordingly, PLS financing is predicted to have a positive impact on NFP. The asset, which measures the size of Islamic bank, may lead to a negative or a positive relationship to NPF. Larger Islamic banks can take more benefits from income diversification and economies of scale than smaller Islamic banks, so it is considered to have a negative impact on NPF (Trad, Trabelsi, \& Goux, 2017). However, large Islamic bank also leads to some control problems in financing, which causes them to lend improperly and may result in higher NPF than smaller Islamic bank (Mirzaei, Moore, \& Liu, 2013). CAR represents the Islamic bank's ability to hold its capital. CAR may have a positive or negative impact on NPF. Higher CAR means that an Islamic bank can expand its business to create more profit, but also more default (Hamid, 2017). Because of higher financing risk from the PLS contracts, Islamic banks may act more prudentially by preserving an extra capital buffer so higher CAR lowers impaired financing (Trinugroho, Risfandy, \& Ariefianto, 2018).

Loan loss provisions (LLP) measure financing quality. Higher provisions represent an inability of borrowers to pay their financing duty in a timely manner. Our study hypothesizes a positive relationship between financing quality and NPF. The ratio of operating expense to operating revenue (OER) measures the efficiency of the Islamic bank. Higher OER lowers efficiency so we expect that a positive relationship between OER and NFP exists. Non-financing income represents a diversification of income. Income diversification (INCDIV) is measured with the following formula (Laeven \& Levine, 2007; Čihák \& Hesse, 2010) as

$$
\mathrm{INCDIV}=\left[1-\left(\frac{\mathrm{FI}-\mathrm{NFI}}{\mathrm{TI}}\right)\right]
$$

FI is financing income, NFI is non-financing income, and TI is total income. Islamic bank, which does not rely more 
on commission or fees, has a lower probability of impaired financing so it links to a negative relationship to NPF (Kabir, Worthington, \& Gupta, 2015). Financing diversification (FINDIV) reflects the concentration of financing. Our study measures financing diversification using the Herfindahl Index of Islamic banks' financing products as (Trinugroho, Risfandy, \& Ariefianto, 2018)

$$
\begin{aligned}
\text { FINDIV } & =\left(\frac{\text { Murabaha }}{\mathrm{TF}}\right)^{2}+\left(\frac{\text { salam }}{\mathrm{TF}}\right)^{2}+\left(\frac{\text { isthisna }}{\mathrm{TF}}\right)^{2} \\
& +\left(\frac{\text { Mudharaba }}{\mathrm{TF}}\right)^{2}+\left(\frac{\text { Musyaraka }}{\mathrm{TF}}\right)^{2}+\left(\frac{\text { Ijarah }}{\mathrm{TF}}\right)^{2} \\
+ & \left(\frac{\text { Qardh }}{\mathrm{TF}}\right)^{2}+\left(\frac{\text { Multifinancing }}{\mathrm{TF}}\right)^{2}
\end{aligned}
$$

TF is total financing. We expect that more diversified financing means less NPF. Studies on financing risk of Islamic commercial banks also include macroeconomic variables to represent the changes in the business cycle. Our study uses the growth of gross regional domestic product (GGRDP) to measure economic upturn and downturn at the province level. High GGRDP leads to a high economic activity so it lowers NPF.

Like NPL for the conventional bank, NPF, which indicates financing risk in Islamic banks, is apparently persistent overtime for every financial intermediary (Hamid, 2017). Considering this stylized fact, the static panel regression in equation (1) does not reflect this condition. The fixed effect (FE) and random effects (RE), which are widely employed, yield biased and consistent estimates (Arellano \& Bond, 1991). Accordingly, we also apply a dynamic panel regression by including lagged NPF variable as one of the independent variables as:

$$
\begin{aligned}
\mathrm{NPF}_{i t}= & \delta_{0}+\delta_{1} \mathrm{NPF}_{i t-1}+\delta_{2} \mathrm{PLS}_{i t}+\delta_{3} \text { LASSETt }_{i t} \\
& +\delta_{4} \mathrm{CAR}_{i t}+\delta_{5} \mathrm{LLP}_{i t}+\delta_{6} \mathrm{OER}_{i t}+\delta_{7} \mathrm{INCDIV}_{i t} \\
& +\delta_{8} \mathrm{FINDIV}_{i t}+\delta_{9} \mathrm{GGRDP}_{i t}+\mathrm{e}_{i t}
\end{aligned}
$$

We employ the two-step system GMM to estimate the dynamic panel regression as in equation (4) (Arellano \& Bover, 1995). The system GMM is more robust than the difference GMM because the later estimator produces both biased and inefficient estimates (Blundell \& Bond, 1998).

\subsection{Data}

Our study employs quarterly data of 142 Islamic Rural banks across the country located in 20 provinces. The observation covers the period from 2013:Q1 to 2018:Q4. We have a balanced panel data consisting of 3,408 observations. All data of Islamic rural bank characteristics are from the
Indonesian Financial Services Authority (www.ojk.go.id). The growth of gross regional domestic product is extracted from the Indonesian Central Bureau of Statistics (www.bps. go.id).

\section{Results and Discussion}

\subsection{Results}

Table 1 exhibits descriptive statistics for all variables being studied. The average NPF was $11.66 \%$ with a standard deviation of 11.72. The average NPF was higher than $5 \%$ as the maximum threshold to be a healthy Islamic rural bank. Islamic rural banks may face higher NPF because they provide funds for small and medium enterprises that may have a higher risk than large enterprises. Average PLS financing over total financing growth was small with an average of $11.47 \%$, and some Islamic rural banks do not provide PLS due to moral hazard, asymmetric information, and adverse selection. The average assets are IDR 49.40 billion, but there is a huge gap among Islamic rural banks because of high standard deviation (IDR 89.60 billion).

CAR is above the threshold of $12 \%$ with an average of $24.32 \%$ and with a standard deviation of 4.1 . High CAR shows that IRB may behave more prudentially due to high NPF. IRBs, therefore, have to provide more additional capital buffer to avoid any possible losses during economic downturns (Louhichi \& Boujelbene, 2017). Loan loss provision is small $(2.68 \%)$, indicating that IBR encounters less risky for their financing. The IRB achieved the efficiency level in operating with OER of $66.64 \%$ which is below the threshold of $94 \%$. However, income diversification was relatively small with an average INCDIV of $20 \%$. The financing product is concentrated (0.74). Unlike conventional rural banks, IRB has limited financing product because any product must be in line with Sharia compliance and is approved by the Sharia Supervisory Board (Waemustafa \& Sukri, 2016). On average, quarterly growth of gross regional domestic output was moderate with an average of $5.25 \%$

Table 2 exhibits the correlation among the independent variables. Overall, the correlation between variables is less than 0.7 . The maximum correlation is -0.67 , which is found between independent variable PLS and independent variable FINDIV. Meanwhile, the rest of the correlation between independent variables is less than 0.55 . Based on the correlation between independent variables, there does appear to worry about the possibility of a multicollinearity problem in our model. 
Table 1: Descriptive statistics for variables

\begin{tabular}{|l|c|c|c|c|}
\hline Variable & Mean & Standard deviation & Minimum & Maximum \\
\hline NPF (\%) & 11.66 & 11.72 & 0.00 & 80.48 \\
\hline PLS (\%) & 11.47 & 15.11 & 0.00 & 78.00 \\
\hline ASSET (IDR billion) & 49.40 & 89.60 & 0.57 & 1220.00 \\
\hline CAR (\%) & 18.49 & 16.73 & 2.06 & 136.71 \\
\hline LLP (\%) & 2.68 & 4.37 & 0.00 & 64.69 \\
\hline OER (\%) & 66.64 & 55.55 & 15.52 & 1947.66 \\
\hline INCDIV & 0.20 & 0.16 & 0.00 & 1.87 \\
\hline FINDIV & 0.74 & 0.20 & 0.26 & 1.00 \\
\hline GRGDP (\%) & 5.25 & 1.87 & -13.88 & 34.08 \\
\hline
\end{tabular}

Note: The number of Islamic rural Banks is 142, covering 2013Q1-2018Q4.

Table 2: Correlation matrix

\begin{tabular}{|l|c|c|c|c|c|c|c|c|c|}
\hline & NPF & PLS & LASSET & CAR & LLP & OER & INCDIV & FINDIV & GRGDP \\
\hline NPF & 1 & & & & & & & & \\
\hline PLS & 0.04 & 1 & & & & & & & \\
\hline LASSET & -0.24 & 0.19 & 1 & & & & & & \\
\hline CAR & 0.28 & -0.16 & -0.54 & 1 & & & & & \\
\hline LLR & 0.57 & -0.10 & -0.23 & 0.29 & 1 & & & & \\
\hline OER & 0.41 & -0.06 & -0.32 & 0.33 & 0.50 & 1 & & & \\
\hline INCDIV & 0.20 & 0.06 & -0.16 & 0.25 & 0.12 & 0.14 & 1 & & \\
\hline FINDIV & 0.03 & -0.67 & -0.19 & 0.14 & 0.12 & 0.09 & -0.12 & 1 & \\
\hline GGRDP & -0.04 & 0.07 & 0.06 & -0.09 & 0.00 & -0.06 & -0.05 & -0.13 & 1 \\
\hline
\end{tabular}

Now, we discuss the results of both static and dynamic panel regressions. Our discussion starts with static panel regression. There are three methods for estimating static panels, namely, pooled regression as a common effect (CE), fixed effect (FE), and random effect (FE). The choice of the static panel regression method is based on the F-test, which tests between $\mathrm{CE}$ and FE, the Bruesch-Pagan test, which examines between $\mathrm{CE}$ and RE and Hausman tests which checks between FE and RE. Čihák and Hesse (2010) prove that Islamic bank performance relies on the Islamic bank's size. Accordingly, we especially investigate the NPF of Islamic banks based on Islamic bank's size. Table 3 shows the estimation results of the static panel model. All diagnostic tests are shown at the bottom of Table 3. Based on the F-test, Bruesch-Pagan test, and Hausman test, the best model for this static panel regression is the fixed effect (FE) model for all Islamic banks sample and larger banks and the random effect for small banks.

We begin with all Islamic banks as baseline regression. PLS financing is a positive sign and statistically significant on NPF. PLS financing, however, has more impact on the NPF of large Islamic banks than that of small Islamic banks. The asset has a positive effect on NPF for large Islamic banks but has a negative effect on NPF for small Islamic banks. A high CAR leads to IRB to have sufficient capital so that it can expand its business and, at the same time, increase the probability of NPF. A positive impact of CAR on NPF applies only to large Islamic banks. Loan loss provisions (LLP) measure financing quality. Loan loss provisions positively affect impaired financing as expected, but the impact of this variable on NPF is stronger for large banks than small Islamic banks. The level of banking efficiency, as measured by OER, has a positive effect on NPF. Inefficiency in operating is a stronger impact on NPF for large Islamic banks than small Islamic banks. Income diversification, however, has a positive impact on NPF for all Islamic banks and small Islamic banks, but it is contrary to our hypothesis. Financing concentration positively impacts NPF for the large Islamic banks. Regional economic growth has a negative impact on impaired financing. Economic upturn lessens NPF and is more powerful impact on small Islamic banks. 
Table 3: Static Panel Regression

\begin{tabular}{|l|c|c|c|}
\hline Variable & All Banks: FE & Large Banks: FE & Small Banks: RE \\
\hline Constant & 7.7008 & $-45.6116^{* * *}$ & $34.2336^{* * *}$ \\
\hline PLS & $(6.3562)$ & $(8.0621)$ & $(9.6115)$ \\
\hline & $0.0985^{* * *}$ & $0.1012^{* * *}$ & $0.0776^{* *}$ \\
\hline LASSET & $(0.0200)$ & $(0.0200)$ & $-1.4965^{* * *}$ \\
\hline & -0.2446 & $2.0057^{* * *}$ & $(0.5444)$ \\
\hline CAR & $(0.3400)$ & $(0.4109)$ & 0.0265 \\
\hline & $0.0870^{* * *}$ & $0.2244^{* * *}$ & $(0.0188)$ \\
\hline LLP & $(0.0160)$ & $(0.0381)$ & $1.3593^{* * *}$ \\
\hline & $1.4495^{* * *}$ & $1.9401^{* * *}$ & $(0.0442)$ \\
\hline OER & $(0.0375)$ & $(0.0846)$ & $0.0070^{* *}$ \\
\hline & $0.0085^{* * *}$ & $0.1323^{* * *}$ & $(0.0031)$ \\
\hline INCDIV & $(0.0027)$ & $(0.0102)$ & $4.2172^{* * *}$ \\
\hline & $1.6343^{* *}$ & -0.9350 & $(1.4945)$ \\
\hline FINDIV & $(0.9658)$ & $(1.1143)$ & -2.0024 \\
\hline & 1.9031 & $7.2894^{* * *}$ & $(2.7504)$ \\
\hline GGRDP & $(1.7089)$ & $(1.8822)$ & $-0.4204^{* *}$ \\
\hline & $-0.1541^{* *}$ & -0.0501 & $(0.1919)$ \\
\hline F (prob) & $(0.0698)$ & $(0.0623)$ & 0.0000 \\
\hline Breusch-Pagan (prob) & 0.0000 & 0.0000 & 0.0000 \\
\hline Hausman (prob) & 0.0000 & 0.0000 & 0.338 \\
\hline
\end{tabular}

Note: ${ }^{* * * ;} ; * ; *$ are statistically significant at $\alpha=1 \%, 5 \%$ and $10 \%$ respectively. Parentheses indicate standard error

The findings of the dynamic panel regression are exhibited in Table 4. The findings clearly show that the lagged NPF variable is positive and significant, confirming that the impaired financing is persistent overtime for both large and small Islamic banks. An Islamic bank that experiences high impaired financing in the previous quarter leads to high bad financing in the current quarter. However, the coefficient of lagged NPF is lower for large Islamic banks than small Islamic banks. It may conclude that NPF is less persistent for large Islamic banks than small Islamic banks. Higher PLS contracts increase the impaired financing, but PLS financing positively influences only large Islamic banks. Loan loss provision positively affects NPF for all cases and it has a stronger impact on larger Islamic banks than small Islamic banks. Inefficiency leads to higher NPF only for larger Islamic Banks. Income diversification lowers the impaired financing for large Islamic banks.

Indonesia is an archipelago country and economic development differs from one island to another. Java is a main island in Indonesia because it is not only the center of the Indonesian economy, but the most developed island as well. Therefore, it is interesting to investigate the nonperforming financing of Islamic banks by splitting the Islamic banks based on economic conditions. Our study divides two regions comprising Islamic rural banks, which is located in Java Island and outside Java Island. Table 5 presents static panel regression for both Java and outside Java Island. PLS financing positively affects NPF for Islamic banks located in Java Island. Higher asset increases bad financing for Islamic banks in Java but lowers impaired financing for Islamic banks outside Java. CAR has a positive impact on NPF for Islamic banks located in Java. Loan loss provision positively affects NPF for all cases. Operating inefficiency positively affect NPF for those Islamic banks in Java. Income diversification increases NPF for Islamic banks in Java, yet it decreases NPF for Islamic banks outside Java. Income diversification has a different impact on Islamic banks in Java and outside Java. It intensifies the former one and lessens for the later one. Economic upturn reduces the NPF for only Islamic banks outside Java. 
Table 4: Dynamic Panel Regression

\begin{tabular}{|l|c|c|c|}
\hline Variable & All Banks & Large Banks & Small Banks \\
\hline NPF $_{\mathrm{t}-1}$ & $0.7277^{* * *}$ & $0.6697^{* * *}$ & $0.6892^{* * *}$ \\
\hline PLS & $(0.0540)$ & $(0.0961)$ & $-0.0850)$ \\
\hline & $0.0478^{* * *}$ & $0.0544^{* * *}$ & $(0.0320)$ \\
\hline LASSET & $(0.0135)$ & $(0.0202)$ & -0.3415 \\
\hline & -0.2026 & -0.0612 & $(1.0484)$ \\
\hline CAR & $(0.1951)$ & $(0.3252)$ & -0.0061 \\
\hline & 0.0150 & 0.0264 & $(0.0268)$ \\
\hline LLP & $(0.0151)$ & $(0.0271)$ & $0.5223^{* * *}$ \\
\hline & $0.4925^{* * *}$ & $0.6016^{* * *}$ & $(0.1276)$ \\
\hline OER & $(0.0950)$ & $(0.1774)$ & 0.0076 \\
\hline & 0.0030 & $0.0337^{* *}$ & $-0.0116)$ \\
\hline INCDIV & $(0.0065)$ & $(0.0182)$ & $(5.0462)$ \\
\hline & $-3.9203^{* *}$ & $-3.5984^{* * *}$ & -2.5024 \\
\hline FINDIV & $(1.4900)$ & $(1.2932)$ & $(3.7709)$ \\
\hline & 0.7672 & 1.3033 & -0.2900 \\
\hline GGRDP & $(1.4330)$ & $(1.4157)$ & $(1.9638)$ \\
\hline & -0.3633 & -0.2368 & 1171 \\
\hline No of observation & $(0.4949)$ & $(0.5062)$ & 63 \\
\hline No of Banks & 2548 & 1377 & 55 \\
\hline No of instruments & 142 & 65 & 0.074 \\
\hline Hansen (prob) & 55 & 55 & 0.442 \\
\hline AR(2) (prob) & 0.066 & 0.366 & \\
\hline
\end{tabular}

Note: ${ }^{* * *} ;{ }^{* * ; *}$ are statistically significant at $\alpha=1 \%, 5 \%$ and $10 \%$ respectively. Parentheses indicate standard error

Table 6 presents the results of dynamic panel regression based on the Islamic bank's location. The lagged NPF variable positively affects the current NPF, ensuring that bad financing is permanent overtime for Islamic banks across the country. The coefficient of lagged NPF is higher for Islamic banks in Java than large Islamic banks outside Java, concluding that NPF is more permanent for Islamic banks in Java than Islamic banks outside Java. The higher proportion of PLS financing increases bad financing, but the coefficient of PLS financing is higher for Islamic banks outside Java than Islamic banks in Java. Loan loss provision positively affects NPF. Inefficiency has a different impact on NPF, where it increases bad financing for Islamic banks in Java, but decreases impaired financing for Islamic banks outside Java. Income diversification lowers the impaired financing both Islamic banks in Java and outside Java. Less diversified financing increases impaired financing for Islamic banks outside Java.

\subsection{Discussion}

Our findings distinctly denote that the lagged NPF variable is positive and significant for all Islamic banks. Islamic banks that encounter high NPF in the previous period also produce high impaired financing in the current period and vice versa. These results imply that NPF is persistent over time for Islamic banks due to such factors as asymmetric information, market competition, and economic shock (Hamid, 2017). Consequently, static panel regression leads to biased and inconsistent estimates. For that reason, we discuss only the results of dynamic panel regression instead of static panel regression. 
Table 5: Static Panel Regression: Islamic Bank's Location

\begin{tabular}{|l|l|l|}
\hline Variable & \multicolumn{1}{|c|}{ Java: FE } & Outside Java: FE \\
\hline Constant & $-33.6291^{* * *}$ & $80.8587^{* * *}$ \\
\hline & $(7.9296)$ & $(10.0453)$ \\
\hline PLS & $0.1304^{* * *}$ & -0.0789 \\
\hline & $(0.0216)$ & $(0.0527)$ \\
\hline LASSET & $1.6501^{* * *}$ & $-3.7189^{* * *}$ \\
\hline & $(0.4120)$ & $(0.5380)$ \\
\hline CAR & $0.1315^{* * *}$ & -0.0305 \\
\hline & $(0.0229)$ & $(0.0205)$ \\
\hline LLP & $1.6153^{* * *}$ & $1.2635^{\star * *}$ \\
\hline & $(0.0557)$ & $(0.0462)$ \\
\hline OER & $0.0667^{* * *}$ & -0.0008 \\
\hline & $(0.0057)$ & $(0.0029)$ \\
\hline INCDIV & $2.2880^{* *}$ & $-2.8746^{* *}$ \\
\hline & $(1.1579)$ & $(1.6051)$ \\
\hline FINDIV & $7.6070^{\star * *}$ & $-9.2175^{* * *}$ \\
\hline & $(2.1328)$ & $(2.8195)$ \\
\hline GGRDP & -0.2273 & $-0.1809^{* * *}$ \\
\hline & $(0.2857)$ & $(0.0630)$ \\
\hline F (prob) & 0.0000 & 0.0000 \\
\hline $\begin{array}{l}\text { Breusch-Pagan } \\
\text { (prob) }\end{array}$ & 0.0000 & 0.0000 \\
\hline Hausman(prob) & 0.0000 & 0.0000 \\
\hline
\end{tabular}

Note: ${ }^{* * ;} ;{ }^{* * ; *}$ are stationer at $\alpha=1 \%, 5 \%$ and $10 \%$ respectively.

Parentheses indicate standard error

Based on the baseline model, the high proportion of PLS contracts increase impaired financing because PLS contracts such as mudharaba and musyaraka produce about moral hazard, asymmetric information, and adverse selection, so it leads to higher impaired financing (Lassoued, 2018). Our results confirm the existing empirical study to which mudharaba and musyaraka produce riskier financing than other financing contracts (Warninda, Ekaputra, \& Rokhim, 2019). Large Islamic banks face riskier impaired financing than small Islamic banks due to a high proportion of PLS contracts because the funding source and financing portfolio of large Islamic banks definitely exceed those small banks. PLS contracts yield to a higher risk for an Islamic bank outside Java than those in Java. The plausible reason is that any financing contract, including PLS contracts, relies on the inability of borrowers to respect their financing obligation, which definitely depends on economic condition. Java Island is the center of the Indonesian economy and most developed Island so Islamic banks in Java deal with less financing risks than those outside Java.
Table 6: Dynamic Panel Regression: Islamic Bank's Location

\begin{tabular}{|l|c|c|}
\hline Variable & Java & Outside Java \\
\hline NPF $_{\mathrm{t}-1}$ & $0.7514^{* * *}$ & $0.5828^{* * *}$ \\
\hline PLS & $(0.0724)$ & $(0.1335)$ \\
\hline & $0.0372^{* *}$ & $0.0803^{* *}$ \\
\hline LASSET & $(0.0199)$ & $(0.0429)$ \\
\hline & -0.1166 & -0.4536 \\
\hline CAR & $(0.2301)$ & $(0.7133)$ \\
\hline & 0.0198 & -0.0138 \\
\hline LLP & $(0.0251)$ & $(0.0285)$ \\
\hline & $0.4883^{* *}$ & $1.1865^{\star * *}$ \\
\hline OER & $(0.1558)$ & $(0.3836)$ \\
\hline & $0.0182^{* *}$ & $-0.0207^{* *}$ \\
\hline INCDIV & $(0.0102)$ & $(0.0107)$ \\
\hline & $-3.2533^{* *}$ & $-2.2960^{* *}$ \\
\hline FINDIV & $(1.7040)$ & $(1.2878)$ \\
\hline & 0.4703 & $5.2859^{* *}$ \\
\hline GGRDP & $(1.5911)$ & $(3.0964)$ \\
\hline & 1.0116 & -0.0565 \\
\hline No of observation & $(2.3390)$ & $(0.2453)$ \\
\hline No of Banks & 1900 & 648 \\
\hline No of instruments & 89 & 39 \\
\hline Hansen (prob) & 55 & 55 \\
\hline AR(2) (prob) & 0.202 & 0.996 \\
\hline Not & 0.358 & 0.781 \\
\hline
\end{tabular}

Note: ${ }^{* * ;} ;{ }^{* * ; *}$ are statistically significant at $\alpha=1 \%, 5 \%$ and $10 \%$ respectively. Parentheses indicate standard error

Loan loss provisions (LLP) have a positive impact on financing risk. High loan loss provisions represent the precautionary reserve of Islamic banks and reflect the Islamic bank's risk profile. The coefficient of LLP is higher for large Islamic banks than small Islamic banks. These results may lead to the conclusion that larger banks seem to have higher credit risk because large Islamic banks could provide more financing than small Islamic banks. These findings are linked to Abedifar, Molyneux, and Tarazi (2013) who reported that large Islamic banks have higher credit risk than small Islamic banks. The coefficient of LLP is lower for Islamic banks in Java than those outside Java, implying that the former Islamic banks face lower credit risk than the later Islamic bank due to better economic conditions in Java as the main Island in Indonesia (Trinugroho et al., 2017). The operational efficiency ratio (OER), which represents the level of efficiency, positively affects NPF for all Models. The findings indicate that inefficient Islamic banks increase impaired financing, implying that less efficient banks are 
riskier. These findings confirm some previous studies such as Rahim and Zakaria (2013) for Islamic banks and Louzis, Vouldis, and Metaxas (2012) for conventional banks. However, an inefficient Islamic bank located outside Java lowers NPF, which is not expected.

All cases show that income diversification (INCDIV) has a negative impact on impaired financing. Income diversification provides Islamic banks to gather much more information from different products, so it helps them to have more experience related to financing and may lower its bad financing These results confirm the previous study both for Islamic banks (Abedifar, Molyneux, \& Tarazi, 2013; Kabir,Worthington, \& Gupta, 2015) and conventional banks (Karim, Chan, \& Hassan, 2010cost efficiency was estimated using the stochastic cost frontier approach assuming normal-gamma efficiency distribution model proposed by Greene (1990; Louzis, Vouldis, \& Metaxas, 2012). Large Islamic banks and Islamic banks located in Java get more benefits by diversifying income to reduce financing risk. Moreover, as expected, less diversified financing, which indicates concentrated financing portfolio also increases the impaired financing for an Islamic bank outside Java because concentrated financing experiences high financing risk.

\section{Conclusions}

Our study investigates the impact of financing products, Islamic bank characteristics, and macroeconomic conditions on the NPF of Islamic rural banks in Indonesia. Our study obviously reveals that NPF is persistent over time for Islamic banks, so that dynamic panel regression is more robust than static panel regression. We split Islamic rural banks based on size and geographical area. Our findings indicate that PLS contracts, loan loss provision, inefficiency, income diversification, and financing diversification affect impaired financing. Our study finds that a high proportion of PLS contracts likely produces high impaired financing. As expected, large Islamic banks experience more financing risk than small Islamic banks and Islamic banks located in a less developed region also encounter more financing risk. Inefficient Islamic banks apparently face high financing risk. Income diversification and more diversified financing certainly lessen financing risk.

Islamic rural banks in Indonesia face a high risk of default because of high non-performing financing. This study finds some important results and needs more attention for Islamic rural banks to mitigate bankruptcy due to high NPF. First, a high proportion of PLS contracts produces high financing risk. Warninda, Ekaputra, and Rokhim (2019) documented that mudharaba and musharakah as PLS contracts, which have clearly different features, seemingly results in the same financing risk. For that reason, Islamic rural banks must be able to determine the optimal level of PLS contracts to alleviate high impaired financing. Second, Islamic rural banks could increase operational efficiency to lessen high financing risk. Lastly, income diversification through particularly non-financing income and diversified financing, especially murabaha as non-PLS contracts, can also reduce non-performing financing.

\section{References}

Abdulle, M. Y., \& Kassim, S. H. (2012). Impact of Global Financial Crisis on the Performance of Islamic and Conventional Banks : Empirical Evidence from Malaysia. Journal of Islamic Economics, Banking and Finance, 8(4), 9-20.

Abedifar, P., Molyneux, P., \& Tarazi, A. (2013). Risk in islamic banking. Review of Finance, 17(6), 2035-2096. https://doi. org/10.1093/rof/rfs041

Arellano, M., \& Bond, S. (1991). Some Tests of Specification for Panel Data: Monte Carlo Evidence and an Application to Employment Equations. The Review of Economic Studies, 58(2), 277. https://doi.org/10.2307/2297968

Arellano, M., \& Bover, O. (1995). Another look at the instrumental variable estimation of error-components models. Journal of Econometrics, 68(1), 29-51. https://doi.org/10.1016/03044076(94)01642-D

Azmat, S., Skully, M., \& Brown, K. (2015). Can Islamic banking ever become Islamic? Pacific Basin Finance Journal, 34, 253-272. https://doi.org/10.1016/j.pacfin.2015.03.001

Beck, T., Demirgüç-Kunt, A., \& Merrouche, O. (2013). Islamic vs. conventional banking: Business model, efficiency and stability. Journal of Banking and Finance, 37(2), 433-447. https://doi. org/10.1016/j.jbankfin.2012.09.016

Blundell, R., \& Bond, S. (1998). Initial conditions and moment restrictions in dynamic panel data models. Journal of Econometrics, 87(1), 115-143. https://doi.org/10.1016/S03044076(98)00009-8

Čihák, M., \& Hesse, H. (2010). Islamic Banks and Financial Stability: An Empirical Analysis. Journal of Financial Services Research, 38(2), 95-113. https://doi.org/10.1007/s10693-0100089-0

Ghenimi, A., Chaibi, H., \& Omri, M. A. B. (2017). The effects of liquidity risk and credit risk on bank stability: Evidence from the MENA region. Borsa Istanbul Review, 17(4), 238-248. https://doi.org/10.1016/j.bir.2017.05.002

Hamid, F. S. (2017). The Effect of Market Structure on Banks' Profitability and Stability: Evidence from ASEAN-5 Countries. International Economic Journal, 31(4), 578-598. https://doi.or $\mathrm{g} / 10.1080 / 10168737.2017 .1408668$

Hassan, M. K., \& Aliyu, S. (2018). A contemporary survey of islamic banking literature. Journal of Financial Stability, 34, 12-43. https://doi.org/10.1016/j.jfs.2017.11.006

Hassan, M. K., Khan, A., \& Paltrinieri, A. (2019). Liquidity risk, credit risk and stability in Islamic and conventional banks. 
Research in International Business and Finance, 48, 17-31. https://doi.org/10.1016/j.ribaf.2018.10.006

Hussein, K. (2010). Bank-level stability factors and consumer confidence-A comparative study of Islamic and conventional banks product mix. Journal of Financial Services Marketing, 15(3), 259-270. https://doi.org/10.1057/fsm.2010.21

Hussien, M.,Alam, M. M., \& Murad, M. W. (2019). The Performance of Islamic Banks During the 2008 Global Financial Crisis: Evidence from Gulf Cooperation Council Countries. Journal of Islamic Accounting and Business Research, 10(3), 407-420. https://doi.org/10.2139/ssrn.2517359

Kabir, M. N., \& Worthington, A. C. (2017). The 'competitionstability/fragility' nexus: A comparative analysis of Islamic and conventional banks. International Review of Financial Analysis, 50, 111-128. https://doi.org/10.1016/j.irfa.2017.02.006

Kabir, M. N., Worthington, A., \& Gupta, R. (2015). Comparative credit risk in Islamic and conventional bank. Pacific Basin Finance Journal, 34, 327-353. https://doi.org/10.1016/j. pacfin.2015.06.001

Karim, M. Z. A., Chan, S.-G., \& Hassan, S. (2010). Bank Efficiency and Non-Performing Loans: Evidence from Malaysia and Singapore. Prague Economic Papers, 19(2), 118-132. https:// doi.org/10.18267/j.pep.367

Laeven, L., \& Levine, R. (2007). Is there a diversification discount in financial conglomerates? Journal of Financial Economics, 85(2), 331-367. https://doi.org/10.1016/j.jfineco.2005.06.001

Lassoued, M. (2018). Comparative study on credit risk in Islamic banking institutions: The case of Malaysia. Quarterly Review of Economics and Finance, 70, 267-278. https://doi.org/10.1016/j. qref.2018.05.009

Le, D. T. T., \& Diep, T. T. (2020). The Effect of Lending Structure Concentration on Credit Risk: The Evidence of Vietnamese Commercial Banks. Journal of Asian Finance, Economics and Business, 7(7), 59-72. https://doi.org/10.13106/jafeb.2020. vol7.no7.059

Louhichi, A., \& Boujelbene, Y. (2017). Bank capital, lending and financing behaviour of dual banking systems. Journal of Multinational Financial Management, 41, 61-79. https://doi. org/10.1016/j.mulfin.2017.05.009

Louzis, D. P., Vouldis, A. T., \& Metaxas, V. L. (2012). Macroeconomic and bank-specific determinants of nonperforming loans in Greece: A comparative study of mortgage, business and consumer loan portfolios. Journal of Banking and Finance, 36(4), 1012-1027. https://doi.org/10.1016/j. jbankfin.2011.10.012

Mahdi, B. S. I., \& Abbes, M. B. (2018). Relationship between capital, risk and liquidity: a comparative study between Islamic and conventional banks in MENA region. Research in International Business and Finance, 45, 588-596. https://doi. org/10.1016/j.ribaf.2017.07.113
Mirza, N., Rahat, B., \& Reddy, K. (2015). Business dynamics, efficiency, asset quality and stability: The case of financial intermediaries in Pakistan. Economic Modelling, 46, 358-363. https://doi.org/10.1016/j.econmod.2015.02.006

Mirzaei, A., Moore, T., \& Liu, G. (2013). Does market structure matter on banks' profitability and stability? Emerging vs. advanced economies. Journal of Banking and Finance, 37(8), 2920-2937. https://doi.org/10.1016/j.jbankfin.2013.04.031

Rachman, R. A., Kadarusman, Y. B., Anggriono, K., \& Setiadi, R. (2018). Bank-specific Factors Affecting Non-performing Loans in Developing Countries : Case Study of Indonesia. Journal of Asian Finance, Economics and Business 5(2), 35-42. https:// doi.org/10.13106/jafeb.2018.vol5.no2.35

Rahim, S. R. M., \& Zakaria, R. H. (2013). Comparison on stability between Islamic and conventional banks in Malaysia. Journal of Islamic Economics, Banking and Finance, 9(3), 131-149. https://doi.org/10.12816/0001618

Sutrisno, \& Widarjono, A. (2018). Maqasid Sharia Index, Banking Risk and Performance Cases in Indonesian Islamic Banks. Asian Economic and Financial Review, 8(9), 1175-1184. https://doi.org/10.18488/journal. aefr.2018.89.1175.1184

Trad, N., Trabelsi, M. A., \& Goux, J. F. (2017). Risk and profitability of Islamic banks: A religious deception or an alternative solution? European Research on Management and Business Economics, 23(1), 40-45. https://doi.org/10.1016/j. iedeen.2016.09.001

Tran, S. H., \& Nguyen, L. T. (2020). Financial development, business cycle and bank risk in Southeast Asian countries. Journal of Asian Finance, Economics and Business, 7(3), 127-135. https://doi.org/10.13106/jafeb.2020.vol7.no3.127

Trinugroho, I., Risfandy, T., \& Ariefianto, M. D. (2018). Competition, diversification, and bank margins : Evidence from Indonesian Islamic rural banks. Borsa Istanbul Review, 18(4), 349-358. https://doi.org/10.1016/j.bir.2018.07.006

Trinugroho, I., Risfandy, T., Ariefianto, M. D., Prabowo, M. A., Purnomo, H., \& Purwaningsih, Y. (2017). Does religiosity matter for Islamic banks' performance? Evidence from Indonesia. International Journal of Economics and Management, 11(2), 419-435.

Waemustafa, W., \& Sukri, S. (2016). Systematic and Unsystematic Risk Determinants of Liquidity Risk Between Islamic and Conventional Banks. International Journal of Economics and Financial Issues, 6(4), 1321-1327.

Warninda, T. D., Ekaputra, I. A., \& Rokhim, R. (2019). Do Mudarabah and Musharakah financing impact Islamic Bank credit risk differently? Research in International Business and Finance, 49, 166-175. https://doi.org/10.1016/j. ribaf.2019.03.002 